Education" (2014), Law of Ukraine "On Education" (2017), Law of Ukraine "On Scientific and Scientific-Technical Activities" (2016) and other documents. The requirements of academic standards are contained in numerous international instruments, such as, for example, the European Charter for Researchers, which defines the requirements for the activities of researchers. The document contains an Ethical Principles section, which stipulates that scientists must adhere to generally accepted ethical standards and fundamental ethical principles in their disciplines, and to broad requirements for research rules. Therefore, the problem of academic integrity in higher education is urgent. In our view, it is important to highlight the experience of the United States as a leader in the world of higher education systems in maintaining high ethical standards in teaching, teaching and research.

The purpose of the article is to analyze the positive experience of providing academic virtue in US higher education for possible implementation in the university environment of Ukraine. M ethods of comparison, systematization of scientific and Internet sources were used to achieve this goal. The use of generalization method has led to the conclusions of the research findings: American higher education has a deep history of academic integrity, so it is extremely useful to investigate the mechanisms of fraud prevention and adherence to the principles of academic integrity. Extrapolation of world experience to the Ukrainian educational space should be considered in order to avoid the risk of inefficiency of the Ukrainian version of academic codes of ethics, and their influence on the improvement of relations within the academic community. Therefore, international experience in providing academic integrity, in particular United States, is important as world universities view dishonesty as a threat to their security and believe that bad habits are the cause of academic failure.

Key words: higher education, academic integrity, code of academic integrity, plagiarism.

удк 376.1:371.1:37.08:378

Володимир Шевченко

Інститут спеціальної педагогіки і психології

імені Миколи Ярмаченка НАПН України

ORCID ID 0000-0003-0119-3206

DOI 10.24139/2312-5993/2019.08/033-042

\title{
РОЗВИТОК ІНКЛЮЗИВНИХ ТА ІНТЕГРАЦІЙНИХ ПРОЦЕСІВ У ПОЛЬЩІ НА СУЧАСНОМУ ЕТАПІ
}

У статті автор висвітлює сучасний розвиток інклюзивних та інтеграційних процесів у Польщі. Були використані методи аналізу, пошуку, систематизації та узагальнення. Автор характеризує підходи та умови до організації інклюзивного навчання; окреслює питання психолого-педагогічного супроводу учнів із особливими освітніми потребами, а також концептуальні основи підготовки корекційних педагогів. Автор зазначає, що хоча на сьогодні в Польщі інклюзивне навчання $\epsilon$ основною формою здобуття освіти дітьми з особливими потребами, проте вони можуть здобувати освіту і в спеціальних закладах освіти, які є альтернативними. Подальших розвідок потребує вивчення інклюзивного навчання дітей із особливими потребами на різних освітніх ланках.

Ключові слова: інклюзивна освіта, інклюзивне навчання, інтеграція, спеціальна освіта, діти з особливими освітніми потребами, психолого-педагогічний супровід, підготовка фрахівців, Польща. 
Постановка проблеми. Питання включення в соціальне середовище осіб із інвалідністю - проблема, яка привертає значну увагу в Польщі. За останні роки спостерігається все більший інтерес до проблем людей із особливими потребами (Коморовська, 2005, с. 43).

Протягом історичного розвитку в Польщі відбувалися зміни у ставленні до осіб з інвалідністю. Вони пройшли тривалий шлях від заперечення та відчуження, соціальної ізоляції до ідеї інтеграції та інклюзії (Коморовська, 2005, с. 44).

Тривалий час основним інститутом виховання дітей із особливими потребами в Польщі були спеціальні школи (Павленко, 2016, с. 25), проте розвиток ідеї інтеграції в шестидесяті та семидесяті роки минулого століття спричинив зростання інтересу до проблем їх виховання й дослідження соціальних відносин між ними (Бабка, 2010, с. 79). Головними ініціаторами таких змін виступали різні асоціації та соціальні організації, батьки дітей із інвалідністю, самі особи з інвалідністю, а також представники державних органів (Коморовська, 2005, с. 45). Інтеграція починалася з розповсюдження знань про можливості та обмеження людей із особливими потребами, а також із пояснення їх відмінностей та того, яка допомога їм потрібна (Коморовська, 2005, с. 46). Відповідно, з кінця 70-х років XX століття популярною стає альтернативна система освіти, яка пропонує інтеграцію та організацію інклюзивного навчання дітей із особливими потребами в умовах закладів загальної середньої освіти (Павленко, 2016, с. 25).

В останні десятиліття польська система освіти, включаючи навчання дітей із особливими освітніми потребами, зазнала значних якісних змін. Ключовим моментом в освітніх трансформаціях стає дитина з «унікальними» можливостями і потребами розвитку та їі особистісна перспектива (Брикова, 2013 , с. 1). Такі особи захищені законодавчими нормами щодо освіти, працевлаштування, реабілітації й соціальної допомоги (Коморовська, 2005, с. 43). Створений новий порядок надання психолого-педагогічної допомоги дітям із особливими освітніми потребами (Брикова, 2013, с. 1), ураховано конкретні труднощі осіб з інвалідністю, підготовку суспільства до зміни менталітету, ставлення до таких людей, що допомогло знайти певні форми потенційно безконфліктного спілкування. Проте, питання інклюзивного навчання дітей із інвалідністю все ще залишається дискусійним та неоднозначним (Коморовська, 2005, с. 44).

Аналіз актуальних досліджень. Розробленням і впровадженням концептуальних ідей інтеграції та інклюзивної форми навчання займалося багато польських учених і педагогів, серед них D. Al-Khamisy, J. Babka, J. Bogucka, K. Ćwirynkało, G. Dryżałowska, E. Gaweł-Luty, A. Komorowska, O. Kotormus, A. Krause, P. Kubicki, A. Kukułka, I. M yśliwczyk, J. Skibska, A. Szpak, G. Szumski, A. Wasilewska, F. Wilczenski, B. Wołosiuk, J. Wyczesany, A. Zamkowska, A. Żyta та ін. Вони зробили 
вагомий внесок у розвиток питань соціальної інтеграції, інклюзії та навчання дітей із особливими потребами.

Також є дослідження, у яких автори використовують різні аналітичні категорії, за допомогою яких можна визначити ефективність реалізації ідеї інтеграції, наприклад, успішність у навчанні, рівень адаптації, соціальні відносини тощо (K. Baranowicz, K. Barlóg, I. Chrzanowska, H. Ochonczenko, G. Milkowska, A. Sakowicz-Boboryko, A. Zamkowska та ін.).

Метою статті $€$ висвітлення розвитку інклюзивних та інтеграційних процесів у Польщі на сучасному етапі.

Методи дослідження: для досягнення поставленої мети і розв'язання поставлених завдань використано комплекс загальнонаукових та спеціальних методів дослідження: аналіз документів, наукових джерел із метою вивчення стану розробленості проблеми, зіставлення, систематизації та узагальнення.

Виклад основного матеріалу. Соціальна інтеграція в Польщі вимагала значних змін у підходах до осіб із інвалідністю, а також пошуку нових принципів та методів організації освіти для дітей із особливими потребами. На сьогодні польська освітня система побудована таким чином, що від самого народження дитина з особливими потребами включена в загальну систему навчання і виховання (Павленко, 2016, с. 26).

Спеціальна освіта в Польщі, яка впроваджує, підтримує й розвиває інтеграційні та інклюзивні процеси, орієнтується на Конвенцію про права інвалідів (ратифікована 2012 року), 70 статтю Конституції і Закон про освіту від 7 вересня 1991 року (зі змінами від 2015 року). Конвенція про права інвалідів містить детальні правила організації умов для навчання та виховання осіб із особливими потребами, а також догляд за ними (Бабка, 2017, с. 203). Польське законодавство, окрім іншого, для навчання осіб із особливими освітніми потребами (цей термін закріплений у нормативноправових документах) передбачає адаптацію змісту, методів організації навчання, використання психолого-педагогічної допомоги та спеціальних форм дидактичної роботи, упровадження індивідуального навчального процесу, форм та навчальних планів (Кубіцкі, 2016, с. 110-111).

Термін «інтеграція» в Польщі був введений в офіційний обіг Міністерством народної освіти в кінці XX століття (Положення № 29 від 4 жовтня 1993 р.). У поясненні зазначається, що в державних дитячих садках та школах можуть бути організовані інтеграційні відділення. Вони організовуються для того, щоб дати змогу учням із особливими потребами здобувати знання та навички в умовах закладів загальної середньої освіти (Коморовська, 2005, с. 46).

Ідея інтеграції, на думку польського вченого А. Халка (А. Hulka), виражається в дотриманні однакових прав для осіб із інвалідністю та повносправними, а також коли для обох груп створюються однакові умови 
максимального, всебічного розвитку. Це дозволяє дитині з особливими потребами бути серед інших (Коморовська, 2005, с. 44).

Олександра Маціж (A. Maciarz) зробила спробу визначити користь від інтеграції. Вона схарактеризувала ії як напрям змін та спосіб організації занять із реабілітації осіб із особливими потребами, задля надання їм можливості приймати участь у житті, мати доступ до всіх соціальних інститутів та формувати позитивне ставлення і психосоціальні стосунки між повносправними та неповносправними (Коморовська, 2005, с. 46).

У кінці 90-х років XX століття система спеціальних закладів для дітей із особливими потребами в Польщі зазнала суттєвих змін та перепрофілювання. Спеціальні заклади стали осередками навчальнометодичних та кадрових ресурсів, що використовуються при інтегрованому та інклюзивному навчанні (Форощук, 2015, с. 159). Замість застарілої структури створені нові - психолого-педагогічні порадні (консультації), які окреслюють освітній маршрут дитини з особливими потребами.

Освітні заклади, які претендували на статус інклюзивних, мали прийняти підхід (метод) «соціальної схеми обмеженості», а також усунути бар'єри, які робили неможливою повну участь дітей із особливими потребами в освітньому процесі (Павленко, 2016, с. 27-28). Також вимогами для ефективного функціонування інтегрованого та інклюзивного навчання в нових умовах стали зменшена кількість учнів у класах, спеціальні кабінети та корекційний матеріал і професійно підготовлений персонал (педагоги загальноосвітніх шкіл, асистенти, логопеди, психологи, реабілітологи, масажисти та ін.) (Коморовська, 2005, с. 48).

Законом Міністерства освіти від 17.11.2010 року «Про принципи організації та здійснення психолого-педагогічної допомоги і підтримки в державних установах освіти» були виділені групи осіб із особливими потребами із:

1) недієздатністю (інтелектуальна недостатність, порушення зору: тотально сліпі і слабозорі, порушення слуху: глухі та слабочуючі, порушення опорно-рухового апарату (включаючи афазії), комплексні порушення, аутизм (включаючи синдром Аспергера);

2) соціальною дезадаптацією;

3) ризиком соціальної дезадаптації;

4) обдарованістю і талантами;

5) специфічними труднощами в навчанні;

6) розладами вербальної комунікації;

7) хронічними захворюваннями;

8) критичними або травмуючими ситуаціями;

9) академічною неуспішністю;

10) занедбаністю, пов'язаною з умовами проживання дитини та їі сім'ї, способом організації дозвілля, комунікативною інтеграцією; 


\section{1) труднощами адаптації, пов'язаними з культурними} відмінностями або зміною освітнього простору (зміна місця навчання у зв'язку з міжнародною міграцією) (Брикова, 2013, с. 1).

Одним із найважливіших питань щодо освіти дітей із особливими потребами в Польщі, а також одночасно і одним із найважливіших рішень, 3 якими зустрічаються батьки, $€$ вибір відповідної форми навчання: загальноосвітньої, інтегрованої або спеціальної (Кубіцкі, 2016, с. 107-108).

Рішення про включення дитини до інтегрованої та інклюзивної форми навчання $\epsilon$ надзвичайно важливим. Воно має бути цілком добровільним. Сім'я дитини з особливими потребами має бути готова зробити усвідомлений вибір освітнього шляху на підставі рекомендацій психолого-педагогічної консультації (Коморовська, 2005, с. 47-48) щодо форм навчання, які найкращі для дитини. Практика свідчить, що $89 \%$ батьків обирають той заклад, який рекомендує консультаційний центр (Кубіцкі, 2016, с. 111).

Консультація також ознайомлює батьків із можливістю повернення учня з інтегрованої або інклюзивної форми навчання до спеціальної школи або продовження навчання за індивідуальною формою у зв'язку з його психологічними особливостями або якщо вибір був таким, що не відповідав очікуванням закладу, дитини чи батьків. Проте, такі важливі рішення приймаються лише командою фахівців (Коморовська, 2005, с. 48).

Можливість отримання освіти у спеціальних закладах надається дітям, які належать до однієї з трьох вищезазначених груп. Решта дітей здобувають освіту в умовах закладів загальної середньої освіти (Брикова, 2013, с. 2).

Станом на кінець 2015 року в Польщі в межах освітньої системи навчалася 161091 учнів з інвалідністю, серед них 47730 з порушенням інтелекту, 28517 - з аутизмом, в т.ч. і синдромом Аспергера, 21883 - з руховими порушеннями, включаючи афазії, 9610 слабочуючих, 7959 слабозорих, 2389 глухих і 365 сліпих. Проте, кількість дітей із особливими потребами постійно зростає. Так, у порівнянні з 2010 роком дітей зі спектром аутизму стало майже в чотири рази більше (Кубіцкі, 2016, с. 109-110).

На сьогодні підготовка дітей з особливими потребами до інтеграції або інклюзивного навчання здійснюється в родині та в спеціалізованих денних центрах для батьків. За півроку перед тим, як віддати дитину до звичайної школи, в Польщі розпочинається робота з батьками і вчителями: активне спілкування, обмін програмами та досвідом (Павленко, 2016, с. 27).

У даний час відомі різні концепції інтегрованого та інклюзивного навчання, зокрема:

- інтеграційні школи - діти з особливими потребами відвідують звичайні класи загальноосвітньої школи;

- інтеграційні заняття - передбачають включення дітей з інвалідністю до занять у звичайних класах; 
- класи співпраці - діти з особливими потребами відвідують певні спільні заняття;

- допоміжні класи - складаються зі спеціальних груп у загальноосвітніх школах;

- підтримка вчителів загальноосвітніх шкіл, тобто включення фахівців певного напрямку спеціальної освіти як додаткових педагогів у класі;

- індивідуальне навчання дітей із особливими потребами за індивідуально складеною програмою, що проводиться вчителями спеціальних та державних шкіл (Коморовська, 2005, с. 47).

Діти з особливими освітніми потребами можуть навчатись у спеціальних закладах освіти, загальноосвітніх школах та школах, які мають спеціальні класи і класи інтегрованого навчання. Також освітні послуги надаються в центрах спеціального навчання і допомоги чи інших освітніх та лікувальних установах (включаючи санаторно-курортне лікування) (Брикова, 2013, с. 3).

у дошкільних установах Польщі у групах інтегрованого та інклюзивного виховання загальна кількість дітей не може перевищувати 20 осіб, з них з особливими освітніми потребами - не більше 3-5, найчастіше це діти з легкими порушеннями (Брикова, 2013, с. 4).

Діти, які мають збережений інтелект, навчаються і виховуються в закладі загальної середньої освіти за загальною програмою. Така форма включення називається в Польщі мейнстрімінг (mainstreaming) «загальний потік», що є синонімом терміну «інклюзія». Тобто, відбувається повноцінне включення дітей із особливими потребами в освітній процес при створенні для цього необхідних умов. У класах «загального потоку» можуть навчатися 1-2 учні з особливими освітніми потребами при максимальній кількості дітей до 30 осіб.

На даний час у нормативно-правових документах Республіки Польща ще немає чіткого визначення поняття «мейнстрімінг». Деякі польські дослідники та педагоги виділяють його як своєрідну форму інтеграції (наприклад, E. Kulesza) (Брикова, 2013, с. 3).

Досвід Польщі свідчить, що інтеграція має позитивний аспект: вчить відповідальності та толерантності; навчає взаємному прийняттю інших; захищає від ізоляції; дозволяє набути досвіду співпереживання; допомагає позбутися егоїзму; показує, що фізичний або психічний стан не впливає на товариські стосунки, не виключає 3 життя класу та школи тощо (Коморовська, 2005, с. 46-47).

Визначальними є питання психолого-педагогічного супроводу учнів із особливими освітніми потребами, що перебувають в умовах інтегрованого та інклюзивного навчання. Оскільки саме надання психолого-педагогічної підтримки дітям із особливими потребами $\epsilon$ найсуттєвішою диференціальною ознакою спеціальної освіти (Форощук, 2015, с. 158). 
Значна увага під час організації спільного навчання дітей із особливими потребами та їхніх однолітків надається роботі з батьками дітей з інвалідністю. Вони мають змогу брати участь у розробці індивідуальних навчальних планів та отримувати консультаційну допомогу фахівців (Форощук, 2015, с. 159).

Дітям із особливими освітніми потребами також надається можливість відвідувати спеціально організовані додаткові форми психологічної та педагогічної підтримки. Вони включають терапевтичні, стимулюючі, навчальні класи, заняття 3 фахівцем (корекційні та компенсуючі 3 мовленнєвої терапії, соціо-терапевтичні заняття) (Брикова, 2013, с. 4).

Аналіз структури учнів із особливими освітніми потребами, які навчаються в спеціальних класах загальноосвітніх шкіл (інтегрована форма) свідчить, що 24,6 \% становлять діти з порушеннями опорно-рухового апарату, на другому місці діти з легким ступенем інтелектуальної недостатності (аналог затримки психічного розвитку в Україні) - 13,1 \%, 11,7 \% - учні $з$ порушенням слуху та зору, 10,9 \% -діти з хронічними захворюваннями, інші категорії дітей складають менше 10 \% (Брикова, 2013, с. 2).

Основним закладом для підготовки педагогічних кадрів у Польщі для роботи з дітьми з особливими потребами є Академія спеціальної педагогіки імені Марії Гжегожевської (м. Варшава). Цим займаються також заклади вищої та професійної освіти і Центри професійного вдосконалення по всій країні.

Університети зорієнтовані на конкуренцію щодо високого рівня підготовки фахівців. Основною метою є відбір і стимулювання до розвитку креативних, ініціативних педагогів, які переживають за реноме та рейтинг університету, а відповідно й за високий рівень надання освітніх послуг і рівень підготовки випускників (Андрощук, 2018, с. 7).

До кандидата на посаду вчителя висуваються вимоги, що стосуються кваліфікації, моральних позицій, відмінного здоров'я. Кваліфікаційні запити на посаду вчителя встановлює стаття 9.1. Карти вчителя, а також ухвала Міністра національної освіти від 10.10.1991 року, у яких зазначається, що посаду вчителя може обіймати особа, яка має вищу освіту з відповідною педагогічною підготовкою або закінчила установу, що здійснює підготовку вчителів і виконує роботу на посаді, для якої $\epsilon$ достатньо кваліфікації; дотримується основних моральних принципів та необхідних умов для виконання професії (Павленко, 2016, с. 28).

Фінансування освіти дітей із особливими потребами в умовах інтеграції або інклюзії здійснюється за рахунок державної субсидії, яка розраховується для кожної дитини на підставі розпорядження Міністра національної освіти та коштів місцевих бюджетів. Витрати на такі форми навчання в порівнянні зі спеціальними закладами перевищують базову ставку на одного учня у 1,49,5 разів залежно від ступеня інвалідності (Кубіцкі, 2016, с. 111). 
В інтеграційних та інклюзивних процесах польської системи освіти також існують проблеми та питання. Узагальнено вони мають такий вид:

- нижча позиція, яку займають діти з особливими потребами у класі;

- обмежені соціальні контакти;

- більша поблажливість до них учителів та зниження вимог;

- певний віковий діапазон учнів у класі, адже діти з особливими потребами зазвичай старші за своїх однокласників;

- неспроможність адаптувати шкільні програми до потреб дитини (Коморовська, 2005, с. 49);

- приділення інтелектуально неповносправним дітям більше часу, ніж вчителі мають можливість;

- ізоляція інтелектуально неповносправних дітей іншими учнями класу (Котормус, 2017, с. 77).

- кількісний розподіл учнів за типами закладів освіти на різних ступенях навчання;

- включення дітей із порушеннями інтелектуального розвитку в систему інтегрованого та інклюзивного навчання (Брикова, 2013, с. 5).

Окрім цього, у Польщі продовжують тривати дискусії щодо того, яка форма навчання найкраща і для кого. Дилеми батьків щодо вибору відповідної форми навчання $€$ наслідком недосконалості освітньої системи та недостатньої узгодженості між теорією і практикою. Це свідчить, що незважаючи на законодавчі зміни, існуюча система не піддається таким трансформаціям легко, а практичний досвід указує на неефективність широкого прийому учнів з особливими потребами до загальноосвітніх шкіл (Кубіцкі, 2016, с. 108).

Висновки та перспективи подальших наукових розвідок. Отже, в Польщі створені сприятливі умови для навчання та інтеграції дітей із особливими освітніми потребами. Існує три основних освітніх маршрути: загальноосвітні школи (мейнстрімінг), інтегровані і спеціальні школи. Інклюзивне навчання та інтеграція - це альтернатива навчанню в спеціальних закладах. Головним їх результатом $€$ те, що дитина вчиться життєдіяльності та взаємодії в суспільстві звичайних дітей, у неї формується спрямованість до повноцінного життя.

Подальших наукових розвідок потребує вивчення інтегрованого та інклюзивного навчання дітей із особливими потребами на різних освітніх ланках.

\section{ЛІТЕРАТУРА}

Андрощук, І. (2018). Стратегічне управління кадровим потенціалом університетів Республіки Польща. Педагогічні науки: теорія, історія, інновачійні технології, 5 (79), 7 (Androshchuk, I. (2018). Strategic Human Resources Management of the Universities of the Republic of Poland. Pedagogical sciences: theory, history, innovative technologies, 5 (79), 7). 
Babka, J. (2010). Wposzukiwaniu nowych wyznaczników spolecznej integracji uczniów niepelnosprawnych i pelnosprawnych. Niepelnosprawnosc. Dyskursy pedagogiki specjalnej, Gdañsk, 3, 79.

Babka, J. (2017). Znaczenie edukacji w procesie wspierania inkluzji społecznej osób z niepełnosprawnością oraz budowania społeczeństwa inkluzyjnego. Społeczeństwo włączajqce a komunikacja. Redakcja naukowa Jacek J. Błeszyński, Ditta Baczała (pp. 197-213), Toruń, Wydawnictwo naukowe uniwersytetu M ikołaja Kopernika.

Брикова, С., Свєтлакова, О. (2013). Організація інтегрованого навчання та виховання дітей $з$ особливими освітніми потребами (досвід Республіки Польща). Спеціальна освіта: традиціі та інновачії (матеріали IV Міжнародної науково-практичної конфреренції, м. Мінськ, 24-25 жовтня 2013 р.) Редкол.: С. Є. Гайдукевич, І. М. Логінова, В. В. Радигіна та ін. Мінськ, БДПУ, 1-5 (Brikova, S., Svietlakova, 0. (2013). Organization of integrated education and upbringing of children with special educational needs (experience of the Republic of Poland). Special Education: Traditions and Innovations (Proceedings of the IV International Scientific and Practical Conference, M insk, October 24-25, 2013) Ed. Gaidukevich, I.M. Loginova, V.V. Radigin et al. M insk, BSPU, 1-5).

Komorowska, A. (2005). Kształcenie integracyjne - szansa czy zagrożenie? Kultura i Edukacja, Torun, 4, 43, 44, 45, 46, 47, 48, 49.

Котормус, О. (2017). Інтеграційна освіта у перцепції батьків. Актуальні питання корекційної освіти (педагогічні науки), 9, 2, 77. (Cormermus, 0. (2017). Integrative education in parents' perceptions. Topical Issues in Correctional Education (Pedagogical Sciences), 9, 2, 77).

Kubicki, P. (2016). Miedzy wlaczaniem a segregacja - szkoly w Polsce wobec uczniow z niepelnosprawnosciami. Niepelnosprawnosc, Dyskursy pedagogiki specjalnej, Gdañsk, 22, 107, 108, 109, 110, 111.

Павленко, В. (2016). Упровадження інклюзивної освіти в Польщі та Україні. Навчання та виховання дітей з особливими освітніми проблемами: теорія та практика, 25, 26, 27, 28. (Pavlenko, V. (2016). Implementation of inclusive education in Poland and Ukraine. Education and upbringing of children with special educational problems: theory and practice, 25, 26, 27, 28).

Форощук, Л. (2015). Організація інклюзивної освіти в країнах Європи. Актуальні проблеми навчання та виховання людей в інтегрованому освітньому середовищі у світлі реалізації Конвенції ООН про права інвалідів (тези доповідей XV Міжнародної науково-практичної конференції, м. Київ, 18-19 листопада 2015 р.), Київ, Університет «Україна», 158, 159 (Foroshchuk, L. (2015). Organization of inclusive education in European countries. Topical Issues of Educating People in an Integrated Educational Environment in the Light of the Implementation of the UN Convention on the Rights of Persons with Disabilities (Abstracts of the 15th International Scientific and Practical Conference, Kyiv, November 18-19, 2015), Kyiv, Ukraine, 158, 159.

\section{PEЗЮME}

Шевченко Владимир. Развитие инклюзивных и интеграционных процессов в Польше на современном этапе.

В статье автор освещает современное развитие инклюзивных и интеграционных процессов в Польше. Были использованы методы анализа, поиска, систематизации и обобщения. Автор характеризует подходы и условия к организации 
инклюзивного обучения; определяет вопросы психолого-педагогического сопровождения учащихся, концептуальные основы подготовки коррекционных педагогов. Автор отмечает, что хотя в Польше инклюзивное обучение является основной формой получения образования детьми с особыми потребностями, однако они могут получать образование и в специальных школах. Дальнейших исследований требует изучение инклюзивного обучения детей с особыми потребностями на разных образовательных звеньях.

Ключевые слова: инклюзивное образование, инклюзивное обучение, специальное образование, дети с особыми образовательными потребностями, интеграция, психолого-педагогическое сопровождение, подготовка специалистов, Польша.

\section{SUM M ARY}

Shevchenko Vladimir. Development of inclusive and integration processes in Poland at the present stage.

In the article the author highlights the contemporary development of inclusive and integration processes in Poland at the present stage. To achieve this goal and solve the tasks set, we used a set of general scientific and special methods of research, namely: analysis of documents, scientific sources to study the state of development of the problem, comparison, systematization and generalization. The author describes the approaches and conditions for the organization of inclusive learning. Notes the reasons why the existing system of inclusive education and integration does not meet the needs of society. Outlines the issues of psychological and pedagogical support for students with special educational needs, who are in the conditions of inclusive and integrative learning. It also defines the conceptual framework for correctional educators, their requirements and their functional responsibilities.

The author points out that the issues of psychological and pedagogical support of students with special educational needs, who are in the conditions of integrated and inclusive learning, are decisive. It is the aspect of psychological and pedagogical support for the joint learning of such children and their peers that is of great importance. As this is related to providing psychological and pedagogical support to children with special needs in the learning process. This is the most significant differential feature of special education.

Much attention is paid to working with parents of children when organizing joint learning of children with special needs and their peers. They have the opportunity to participate in the development of individual curricula, to receive consultative assistance from specialists, etc.

Compared to the pre-reform period, the system of special institutions for children with special needs in Poland has undergone significant reductions and re-profiles. However, it continues to function. Special institutions have become the focal points of teaching and staff resources used in integrated and inclusive learning.

An analysis of the experience of teaching children with special needs in Poland shows that, in the vast majority, inclusive education is the main form of education for them. However, children with special needs have the opportunity to receive education at special education institutions.

Key words inclusive education, special education, children with special educational needs, integration, psychological and pedagogical support, specialists training, Poland. 